\author{
Никос Чаусидис \\ chausidis@gmail.com
}

\title{
Премин преку тесниот мост - меѓу митот, обредот и циркуската точка
}

\begin{abstract}
. Чаусидис Никос, Премин преку тесниот мост - меѓ митот, обредот и циркуската точка (Crossing the narrow bridge - among the myth, the rite and the circus act). „Poznańskie Studia Slawistyczne” 2. Poznań 2012. Adam Mickiewicz University Press, pp. 71-93. ISBN 978-83-232-2409-9. ISSN 2084-3011.
\end{abstract}

All of the elements present within the contemporary phenomenon known as 'circus' can be found in the symbolic traditions of ancient and archaic cultures, most often manifested as mythical pictures, ritual and magical acts, mythical stories and cult objects. In several previous studies we have tried to find the visual, mythical and symbolic ancient models of some classical circus acts, such as the trapeze, juggling and fire-eating. This paper discusses the act of tightrope walking. The introductory part presents basic information regarding this circus act, along with the phrases, elements and skills it consists of. The text continues with a historical review of this circus skill, which reaches as far back as the great civilizations of the Old World. As a mythical paradigm of this act we took the mythical representations from all over the world regarding crossing the mythical bridge conceived in its cosmological dimension - as communication through the cosmic horizons (sky-earth-underworld). This paper reviews several variants of mythical representations of the narrow bridge between 'this world' and the 'underworld' registered in different parts of the planet and originating from different ages: the log i.e. a tree trunk bridge, a snake bridge, a phallic bridge, blade bridge, and the hair i.e. string bridge.

Keywords: circus, tightrope walking, hair bridge, blade bridge, snake bridge

Сите елементи присутни во рамките на современиот феномен познат под називот „циркус” можат да се пронајдат во симболичките традиции на древните и архаични култури, најчесто манифестирани во вид на митски слики, обредно-магиски дејствија, митски раскази и култни објекти. Тука ја имаме предвид самата циркуска арена и шатор, циркуските жанрови и точки, како и главните ликови 
и реквизити. Истражувањата покажуваат дека класичните циркуски точки не настанале поради простата игра и празната забава, ниту пак поради чистото естетско т.е. уметничко доживување кај публиката. Секоја од нив крие во себе некоја исконска смисла и некаква дамнешна желба, преку претставената слика и изведеното дејствие, да се препознае, открие, објасни, претстави и поттикне одреден космички или културен феномен (некогаш многу важен за луѓето), или пак некоја архетипска симболичка структура длабоко вкоренета во човековата потсвест. Забавните и уметничките аспекти на циркусот не можат да се негираат. Тие егзистираат денес, а постоеле и при оформувањето на секоја од циркуските точки - уште во рамките на нивната обредна фаза. Сега е променет само балансот на овие аспекти. Обредниот некогаш бил во прв план, додека уметничкиот и забавниот произлегувале од него како сетилно задоволство на гледачите и изведувачите, базирано врз глобалната религиска вредност на изведбата и емоционалниот афинитет кон неа. Во нашево време, на преден план се ставени токму спомнатите сетилни сфери, при што семиотичките, т.е. сферите на значењето и вредувањето на самите дејствија се привидно елиминирани, односно обесмислени. Привидно, затоа што симболичката вредност на циркуските точки е неизбришлива, поради што таа само се спуштила, од сферите на рационалното и на јавно манифестираната култура, во сферите на потсвесното, каде интерферира со некои исконски архетипски претстави. Токму на овој начин и може да се објасни толкавата моќ на циркусот, кој опстојува до денес, наспроти неговата културна и особено религиската маргинализација, ниското естетско вреднување (во споредба со елитните форми на уметноста) и битката со современите електронски мас-медиуми.

Во неколку наши претходни истражувања се обидовме да ги пронајдеме архетипските визуелни и митско-симболички прамодели на некои класични циркуски точки, како што е трапезот, жонглирањето и голтањето оган ${ }^{1}$. Во овој труд тоа ќе биде точката „одење по јаже”.

\footnotetext{
${ }^{1}$ Нашите први глобални согледувања на оваа тема ги претставивме преку рефератот „Циркус између обреда, игре и уметности: прилог космолошким аспектима класичне циркуске тачке”, презентиран на научната конференција „Традиционална естетска култура: Игра", одржана во Ниш (12.02.2010.) во организација на Центарот за научни истражувања САНУ и Универзитетот во Ниш. Од овој реферат произлегоа уште две засебни студии и тоа за трапезот (Н. Чаусидис, Љуљашка и љуљање између
} 


\section{1. Циркуската точка ,одење по јаже”}

Постојат разни циркуски точки чија основа е одењето по јаже (или во поново време по жица) кое е распнато хоризонтално или косо, меѓу два столба или две платформи (Т. I: 2, 4; Т. III: 5). Движењето по јаже се изведува со или без помош на балансир - долга шипка која се држи хоризонтално во рацете, а е наменета за одржување на рамнотежата (T. I: 5; T. II: 4, 6; T. III: 3). Артистот - изведувач на оваа вештина, се нарекува одач по јаже, funambule (франц.), ropewalker (англ.), канатоходец (рус.), а во своите вештини пред се́ вклучува акробатика, эквилибристика и гимнастика. Освен одењето по јажето, неговите точки вклучуваат и трчање, скокови, танци, жонглирање и возење разни велосипеди (T. I: 3 ; T. II: 2$)^{2}$.

На само чекор од оваа вештина е и спортската гимнастичка вештина позната како „греда”, чија суштина исто така се состои во вешто чекорење, и тоа овој пат по дрвена греда (долга $500 \mathrm{~cm}$ широка $10 \mathrm{~cm}$, издигната од подот на височина од $124 \mathrm{~cm}$ ), проследено со разни други сложени и опасни пози и движења (шпага, скокови, стој на раце, салто, висење). Оваа вештина, денес е официјално прифатена само како женска спортска дисиплина (Т. III: 2$)^{3}$.

\section{a) Историја}

Вештините на одење по јаже се присутни во традициите на разни култури ширум светот, при што во секоја од нив тие носат специфични обележја. Нивната историја може да се следи наназад до древните цивилизации на Египет, Кина и Рим. Кинеските изведувачи, на јажето реализирале танци со топки, при што под нив биле ставани

обреда, игре и уметности, во: Традиџионална естетска култура: Игра, ред. Д. Жунић, Ниш 2011) и за жонглирањето (N. Chausidis, Juggling and its Mythical Paradigms in the Pictorial Medium, во: Jubilee Collection, dedicated to the $70^{\text {th }}$ anniversary of Prof. DSc Ivan Marazov, Sofia 2012). Точката „голтање и исфрлање оган од устата” беше анализирана во рамките на едно наше поранешо истражување (N. Čausidis, The Black Man in the Mythical Tradition of Macedonia, во: Interpretations, vol. 3, Figures of Memory: Black Arab, yp. K. Kulavkova, Skopje 2009).

${ }^{2}$ А.Я. Шнеер, Р.Е. Славский, Цирк: маленькая энциклопедия, Советская энциклопедия, Москва 1973, стр. 49 (баланс, балансирование, балансер, балансир /франц. balance, буквално - вага/), стр. 141-143 (канат), стр. 247 (проволока).

${ }^{3}$ Balance beam, Wikipedia, The Free Encyclopedia. 
ками свртени со сечилата нагоре. Во римската епоха (T. I: 1) е забележено дека одачите по јаже (наречени circulatores) во своите точки, изведувани над базен или река, демонстрирале и прецизно гаѓање со лак, завршувајќи го својот настап со ефектен скок во водата. Оваа вештина била мошне распространета и кај разни народи од Средна Азија, Кавказ и Ерменија, каде акробатите често оделе боси по јаже изработено од волна, распнато на голема височина, при што тие балансирале со садови полни со течност. Во овие точки се вклучувани и разни декоративни елементи, како и сцени проследени со изведба на текстови, често со комичен карактер. Во 14. век Никифор Григора направил детален опис на една ваква точка изведувана во Константинопол од страна на египетски одачи по јаже, а слични настани во 12, 13. и 14. век се документирани и во Русија и Франција. Овие сцени најдоа свое место и во романичката камена пластика (T. I: 6) и гравурите од средниот и новиот век (Т. I: 4, 5). Во 16. век, во Европа биле распространети претставите на одење по јаже кое се издигало косо на големи височини, обично распнато меѓу градскиот мост и врвот на некоја од градските кули или камбанарии (Т. II: 3). Одачите по јаже најчесто настапувале на плоштадите и тоа како еден вид забава за народните маси, така што при оформувањето на првите стационарни циркуси, во 80-те години на 18 . век, оваа точка станува нивен составен дел. Почнувајќи од 19. век, оваа вештина добива во својата драматичност и тоа поради сериозноста на својот зафат (премин на големи реки како Темза, Сена и Нева), но и пропагандните кампањи на сензационалистичкиот дневен печат. Врвот на овие тежнеења, во 1859 г. ќе ги достигне артистот Блонден (Charles Blondin), кој помина по жица распната над Нијагарините водопади (T. III: 3). Во поново време (1974 г.), сличен подвиг реализира Филип Пети (Philippe Petit) поминувајќи по жица распната меѓу двата облакодери-близнаци на светскиот трговски центар во Њујорк (Т. II: 4). Во рамките на современата циркуска точка „одење по јаже”, освен луѓето, како изведувачи се вклучуваат и животни (глувци, мечки, мајмуни, па дури и слонови $)^{4}$.

${ }^{4}$ А.Я. Шнеер, Р.Е. Славский, ор. cit., стр. 13, 141-143; В.П. Даркевич, Народная культура средневековья. Светская праздничная жизнь в искусстве IX-XVI вв., Москва 1988, стр. 20-23; С.М. Макаров, Шаманы, масоны, иирк. Сакральные истоки иирко- 


\section{б) Семиотика и симболика}

Наспроти својата привидна семантичка неутралност, циркуската точка „одење по јаже” е исполнета со мошне силни симболички елементи. Поради тоа, во некои средини, како на пример во Ерменија, нејзините автохтони традиционални изведувачи биле окружени со магична т.е. божествена сила. Во Узбекистан се сметало дека одачот по јаже е поблиску до Севишниот, поради што до него ќе дојде побргу молитвата со молби за исполнување на желбите на присутната публика. Христјанските отци, на одачите по јаже гледале како на грешни луѓе исполнети со „бесовска мудрост” и „ѓаволски привид”, покрај другото и поради ставањето на својот живот на коцка, што не било во согласност со христијанските принципи. Но, постепено оваа напнатост ќe се неутрализира преку изнаоѓање компромисни решени$\mathrm{ja}$, на пример со дополнување на овие точки со христијански симболи (држење свеќи во рацете), при што одењето нагоре по јаже кое е косо оптегнато кон врвот на градската камбанарија ќе добие значење на патување на христијанската душа од ,земскиот” кон „небескиот дом”. Ерменско-грегорјанската црква, дури ќе го прогласи Св. Карапет за покровител на оваа и други циркуски вештини 5 .

Симболичките елементи во циркуската точка „одење по јаже” не функционираат само како одделни компоненти, туку заокружуваат и една посложена семиотичка структура, зад која стојат некои универзални митолошки парадигми. Сосем е евидентно дека поради ризикот од паѓање, одењето по јаже ја симболизира категоријата „опасно движење", зад која можат да застанат бројни реални феномени од човековиот живот (раѓање, иницијација, брак, патувања, болест, смрт ...). Ваквото значење се засилува доколу јажето е распнато на поголема височина, која при евентуалниот пад на изведувачот, би предзвикала негова смрт или сериозни повреди (Т. III). Оваа компонента на фаталност се засилува уште повеќе во очите на публиката ако под жицата се најдат разни дополнителни драматуршки елементи.

вого искусства, Москва 2009, стр. 29, 32, 34, 62, 63, 86, 87, 93, 221, 222, 225, 226, 253; A history of circus, во: Victory and Albert Muzeums (high vire); Charles Blondin, Wikipedia, The Free Encyclopedia; Philippe Petit, Wikipedia, The Free Encyclopedia.

${ }^{5}$ В.П. Даркевич, ор. cit., стр. 22; С.М. Макаров, ор. cit., стр. 32, 63, 86, 87. 
Тоа може да биде некаква „опасна вода” (длабока река, езеро, водопад) (Т. III: 3) оган, страшни животни (лавови, отровни змии, крокодили) или предмети кои можат да повредат (сечила, шилци, искршено стакло). Согледани на рационално ниво, овие елементи не го засилуваат суштински ризикот на изведувачот, бидејќи неговиот пад од жицата би бил опасен и без нивното присуство. Според тоа, овие компоненти се тука за да ја „гаѓаат” публиката на семиотичко т.е. ирационално-симболичко ниво. Всушност, дополнителениот страв кај неа го предизвикува самото нивно присуство како симболи и нивните потенцијални архетипски релации во однос на изведувачот (,ке го проголта длабоката вода”, „огнот ќе го јаглениса неговото тело”, „лавовите жив ќе го изедат”, ,змиите ќе му го обвијат телото”).

Вториот архетипски аспект кој оваа точка ја прави драматична е самиот премин од едниот кон другиот крај на јажето, сфатен како трансфер од една во друга состојба, што во принцип, во човековата потсвест резултира со чувство на напнатост и несигурност. Во рамките на овие точки, јажето не се распнувало само водорамно, туку често пати и косо, што на движењето му давало не само хоризонтална (лево - десно), туку и вертикална димензија (долу - горе) (Т. II: 3 ).

Поради наведените компоненти, со истата тензичност се набиени и други феномени кои на прв поглед изгледаат и функционираат како вовобичаен дел од човековиот секојдневен живот. Тука пред се мислиме на патот и патувањето и особено преминувањето преку мост како негова најкритична фаза. Овој опасен премин, во човековите традиции се издвоил како моќен симбол, универзален за сето човештво, кој се интегрирал во сите форми на културата, особено оние од сферата на митот и религијата. Негативните аспекти на ова дејствие, т.е. тешката проодност на мостот, во митските форми се обликувале во митологемата, премин преку исклучително тесен и кревок мост". Релациите на оваа митологема со вештината на

6 За наведените значења на мостот: В.Н. Топоров, Мост, во: Muфы народов мира, II, Советская энииклопедия, Москва 1982, стр. 176, 177; J. Chevalier, A. Gheerbrant, Rječnik simbola, Zagreb 1987, стр. 416; M. Elijade, Šamanizam i arhajske tehnike ekstaze, prev. Z. Stojanović, Novi Sad 1985, стр. 350-353; V. Matić, Psihoanaliza mitske prošlosti, Beograd 1976, стр. 43-48; Е. Водинчар, Митологично-езическите централии в "историческата" песен за Тодорка Робинка, Електронно списание „LiterNet” 08.01. 
одење по јаже, беше повод во ова наше истражување да ги презентираме разните нејзини варијанти кои според наше мислење можат да се земат како митско-симболичка парадигма на овој циркуски жанр.

\section{2. Претставите за премин преку митскиот мост}

Во традиционалните култури, оваа митологема најчесто носи космолошко значење, одразувајќи ги претставите поврзани со преминот од „овој свет” т.е. земјата и светот на живите кон „оној свет” т.е. небото и „светот на боговите”, или пак кон подземјето т.е. „светот на мртвите". Според некои митови, во идеалното примордијално доба, тој мост не постоел затоа што земјата и небото биле поврзани, луѓето и боговите биле во постојан и непосреден контакт, поради што не егзистирала ниту смртта. Денешната ситуација на поделеност на двата света, во овие митови се поврзува со прекинот на ваквата состојба, со што, некогаш вообичаениот премин од едниот кон другиот свет станал можен само преку некакво трансцендирање т.е. укинување на нивните спротивставености. Тој процес се во состојба да го изведат само некои категории суштества кои поседуваат одредени доблести и способности и тоа под посебни околности :

- Хероизирани луѓе. Тие го преминуваат овој мост за време на реализацијата на своите херојски дела, при што успешниот премин зависи од нивната сила, храброст, решителност и вера, како и од наклонетоста на боговите во однос на нив.

- Богови и полубогови. Преминот се случува за време на нивното спуштање на земјата и враќањето назад на небо. Без разлика на својата семоќност, дури ни тие тоа не го прават било каде, туку преку некаков митски мост и други слични објекти кои го содржат во себе

2001, no. 1 (14), <http://liternet.bg/publish2/evodinchar/todorka.htm> [превземено: 06.01. 2011]; A. Stone, The Perilous Bridge, „At the Edge” no. 1, 1996, <http://www.indigo group.co.uk/edge/pbridge.htm> [превземено: 25.12.2011].

${ }^{7}$ M. Elijade, op. cit., стр. 350-353, примери и толкувања на разни традиции во кои мостот се појавува како граница и врска меѓу световите: стр. 109, 117, 118, 144, 162 164, 204, 215, 219, 225, 235, 246, 247, 283, 284, 292, 293, 306, 314, 315, 322, 325, 326, $331,332,355,357$. 
значењето на „центарот” т.е. „оската на вселената” (космичкиот столб, космичката планина, космичкото дрво, и мостот меѓу небото и земјата).

- Покојници. Услов да се помине мостот меѓу „овој свет” (светот на живите) и „оној свет” (светот на мртвите) е да не припаѓаш на кегоријата „човек”. Поради тоа, мостот го преминуваат само духовите т.е. душите на покојните луѓе кои со својата смрт го промениле тој статус.

- Шамани и други категории посветени луѓе. Сепак, космичкиот мост се во состојба да го преминат и некои категории луѓе. Тоа се оние кои под одредени околности (симболичка смрт) го менуваат својот статус од категоријата „човек” во насока на категоријата „дух”. Едни од нив се шаманите кои ја достигнуваат таа состојба преку екстаза, т.е. транс, присуство во некој сакрален простор и други компоненти. Во јужнословенските обредни песни, мост се гради за коледарите кои треба да дојдат во селото од некое неопределено место (,оној свет”) ${ }^{8}$. Може да се претпостави дека таквото движење се базира врз две компоненти:

- без разлика што се реални деца, коледарите во рамките на обредот функционираат како еманација на новородениот бог, што значи дека имаат божествен статус;

- овој процес се случува во „светото време” (почеток на Новата година т.е. новата космогонија), кога е можно повторно воспоставување на идеалната примордијална врска меѓу космичките нивоа.

\section{3. Митските претстави за тесниот мост меѓу и ,овој” и ,оној свет"}

Во разни делови на светот и разни историски периоди се евидентирани разновидни митски форми во кои се претставува тешкиот и опасен премин преку мост кој го поврзува „овој” и „оној свет”, земјата и небото, светот на живите и светот на боговите или на

8 Л.Н. Виноградова, Мост, во: Славянские древности (Этнолонгвистический словарь), т. 3, Международные отношения, Москва 2004, стр. 306; В.Н. Топоров, op. cit., стр., 177; Е. Водинчар, op. cit. 
мртвите, преминот меѓу пеколот, чистилиштето и рајот. Под овој „мост на проверката" и „мост на смртта" обично се наоѓа длабока бездна, огнена или некаква друга митска река кои се неретко населени со разни опасни животни или негативни демонски суштества (T. II: 5). Во разни митски форми (митови, песни, приказни, преданија, ликовни претстави) тешкиот и опасен премин е кодиран на разни начини (присуство на опасни суштества, нестабилност на мостот, и т.н.) ${ }^{9}$. Во оваа пригода, во релација со тука обработената циркуска точка, ќе ги елаборираме варијантите во кои овој мост е претставен како исклучително тесен т.е. тенок. Малата широчина и дебелина на мостот, а со тоа и тешкиот и опасен премин преку него, во митовите е опредметен преку неколку различни симболички форми кои ги кодираат наведените категории.

\section{а) Мост од трупец т.е. стебло}

Во етнографските традиции на Србите од Источна Србија и од делови на Унгарија и Романија се забележени верувања дека покојникот преминува на оној свет преку ,рајскиот мост” - всушност тесно стебло положено преку длабока пропаст, на чие дно се наоѓа ,jад” (загадена вода полна со „гамади”, влекачи и гадни инсекти). Кај мостот стојат судиите кои решаваат која душа ќе помине, а која не. Праведните поминуваат лесно, а грешните паѓаат во ,јадот” каде се мачат, се прочистуваат и дури потоа преминуваат во рајот. Аналогни верувања за тесен и лизгав трупец т.е. летва, поставени меѓу рајот и пеколот или чистилиштето се забележени и во другите словенски региони (бугарско Подунавје, Полесје) ${ }^{10}$. Овие претстави нашле одраз и во обредните постапки поврзани со погребот или поменот на покојникот. Станува збор за обичајот на положување трупец, даска или мовче преку некој поток, преку друга водна површина или мочурливо место, со цел да и се помогне на неговата душа да премине на „оној свет”. Во некои подрачја, на трупецот се означувало времето

${ }^{9}$ В.Н. Топоров, ор. cit., стр. 176, 177; J. Chevalier, A. Gheerbrant, op. cit., стр. 416; M. Elijade, op. cit., стр. 350-353; V. Matić, op. cit., стр., 43-48; Е. Водинчар, op. cit.; A. Stone, op. cit.

${ }^{10}$ С. Зечевић, Култ мртвих код Срба, Београд 1982, стр. 27-29; Л.Н. Виноградова, ор. сіt., стр. 305. 
на смртта на покојникот, после што присутните седнувале на него и се частеле во чест на неговиот покој. Кај словените, вакви обичаи постоеле и во средниот век, за што сведочат некои средновековни црковни ракописи во кои тие се критикуваат како пагански ${ }^{11}$. Тесниот мост меѓу световите, претставен во вид на стебло, или обична греда, бил присутен и во други култури. На пример, во старогрчката митологија, такво стебло положува меѓу двата света Зевс, за преку него да помине убавата Ирида - неговата гласничка и навестувачка на добри вести. Мошне е индикативно што таа е изедначувана со божилакот, кој пак и самиот по себе бил често претставуван како мост ${ }^{12}$.

За онаа девојќа која сакала да открие со кого ќе се омажи, во јужнословенскиот фолклор се препорачувало таа, преку некаква вода да постави фурка или друг предмет во вид на мостче. Наводно, оваа постапка ќе ја предизвика, во наредните ноќи да сонува како преминува преку вода, и тоа во придружба на својот иден сопруг ${ }^{13}$. Во оваа метафора преминот на водата го симболизира преминот на сонувачката од статусот на девојка во статус на невеста, при што тука воопшто нее е случајно присуството на фурката, со оглед на нејзиното значење на парадигматичен симбол на обата стадиуми на жената ${ }^{14}$.

\section{б) Мост од змија}

Мотивот на митскиот мост сочинет од телото на змија е евидентиран во разни делови на светот: Источна Африка, Кавказ, Мала Азија, Сибир, Меланезија и повеќе региони на Американскиот континент. Во повеќето случаи се работи за реална змија

${ }^{11}$ С. Зечевић, ор. cit., стр. 29; Л.Н. Виноградова, ор. сіt., стр. 305.

12 J. Chevalier, A. Gheerbrant, op. cit., стр. 416; Д. Срејовић, А. Цермановић, Речник грчке и римске митологије, Београд 1987, стр. 169, 170. За божилакот како мост: M. Elijade, op. cit., стр. 116-118; В. Софрониевски, По трагите на божилакот, „Годишен зборник на филозофскиот факултет” 62, 2009, стр. 367-369; Н. Чаусидис, Космолошки слики (симболизачија и митологизащија на космосот во ликовниот медиум), т. I, Скопје 2005, стр. 77, 293, 335.

${ }^{13}$ С. Янева, Предящата Богородица, во: Пıтор - изследвания в чест на проф. Иван Маразов, ред. Р. Гичева, К. Рабаджиев, Анубис, София 2002, стр. 137.

${ }_{14}$ М.М. Валенцова, Прялка, во: Славянские древности (Этнолонгвистический словарь), т. 4, Международные отношения, Москва 2009, стр. 331-334. 
која некогаш е застапена со некој конкретен вид (на пример анаконда) или преку некој локален митологизиран лик. Во поретки случаи се работи и за пар змии, за змијска кожа или за натприродна т.е. митска змија (на пример, со повеќе глави на обете страни од телото). Застапени се и животни кои по форма се слични на змија (гуштер, гасеница). Во некои примери, мостот - змија се изедначува со божилакот кој самиот по себе исто така се претставувал како змија или змеј. Основното дејствие се состои во претворањето на змијата во мост по кој потоа се движат разни категории луѓе, преминувајќи ја водата т.е. бездната. Во најголемиот број случаи, по ваквиот мост одат мртвите т.е. душите на умерените, а во некои случаи, во дејствието се вклучуваат и шамани кои го помагаат т.е. овозможуваат ваквиот премин. Во еден пример, неговото постоење се поврзува со идеалното примордијално доба кога луѓето можеле слободно да се движат низ светот, а кое се пореметило со капнувањето менструална крв врз овој мост - змија ${ }^{15}$.

Поради своето долго тело слично на јаже, змијата функционира како симбол на дистанците, поврзувањата и преминувањата и тоа како во просторна, така и во временска смисла: како оска на светот; врска меѓу небото, земјата и подземјето; светот на живите и светот на мртвите; врска меѓу минатото, сегашноста и иднината. Со своето тенко, лизгаво и еластично тело, но и агресивноста, таа ги засилува опасните белези на митскиот мост: го укрутува своето тело за оние што треба успешно да преминат; се опушта и мрда кога поминуваат непожелните; каснува или проголтува некои од патниците ${ }^{16}$. Во некои култури (вклучително и словенскиот фолклор), оваа митологема е позната во имплицитна форма - како фантастична змија (т.е. змеј) која се протега од небото до земјата, интерферирајќи со божилакот и со космичката оска (кои пак, од своја страна, функционираат како мост меѓу космичките зони) $)^{17}$.

${ }^{15}$ Ю.Е. Березкин, Тематическая классификация и распределение фольклорно-мифологических мотивов по ареалам (Мотив: I 24. Мост-змея).

${ }^{16}$ Ibidem.

17 За космичката оска како змија или змеј: Н. Чаусидис, Космолошки.., стр. 217, 242, 292, 295. За божилакот - змија: В. Софрониевски, ор. сіt., стр. 366-367; Н. Чаусидис, Космолошки..., стр. 288, 292, 293, 370, 374. 


\section{в) Мост од фалус}

И овој мотив е евидентиран во разни делови на светот, што говори за неговиот архетипски карактер (Јужна Азија, Индокина, Тајван, Јужен Сибир делови на Американскиот континет). Во митовите се говори како некој реален човек, натприроден антропоморфен лик (џин) или животно (орел), го потставува својот фалус преку река или море за по него да преминат луѓе. Во некои случаи (поради падната искра или клукнување на птица) фалусот - мост ја губи својата цврстина и некои луѓе паѓаат во водата. Во други примери, сопственикот на фалусот има негативен предзнак - ги напаѓа и силува жените. Аналогно на змијата, оваа митологема се базира врз некои реални но хиперболизирани обележја на машкиот полов орган (должина, цврстина, променливост на формата и својствата). Може да се претпостави дека во некои случаи, како и змијата, значењето на мост произлегло од релациите со митологемите за ,макрокосмичкиот фалус" т.е. фалусот сфатен како космичка оска т.е. столб на светот ${ }^{18}$. Мора да се напомене дека во обата случаи, овој елемент ја остварува истата функција на посредник меѓу „овој и оној свет”. Оваа функција има и своја реална основа, земајќи предвид дека фалусот е навистина медијатор т.е. елемент кој посредува во спојот, поврзувањето т.е. општењето меѓу мажот и жената. Коитусот како негов реален амбиент, ставен во макрокосмички контекст резултира со претставите за светиот брак т.е. хиерогамијата, каде мажот и жената се изедначени со небото и земјата, при што фалусот уште понепосредно се идентификува со космичката оска којашто нив ги поврзува ${ }^{19}$.

\section{г) Мост од сечило}

Во рамките на хиндуистичката култура (Katha Upanisad, III, 14) се вели: „Тешко е да се пројде низ острото сечило на брич, велат поетите за да ја изразат тескобноста на патот (кој води кон највисо-

18 За фалусот како космички столб: Н. Чаусидис, Космолошки..., стр. 61, 64, 65, $374,380,382$.

${ }^{19}$ Ibidem, стр. 374-383; Н. Чаусидис, Хиерогамија и њене ликовне претставе у древним и архаччним културама. Традиционална естетска култура, во: Ерос, прир. Д. Жунић, Ниш 2012. 
кото сознание)". Во средновековните европски легенди се говори за мостот-сабја „поостар од коса” по кој херојот Ланселот „низ патења и маки" мора да помине голорак и босног (T. IV: 3-5). Се смета дека овој мост го симболизира иницијациското искушение т.е. надминувањето на стравот, и тоа преку чинот на храбро соочување со привидната опасност. Во финските преданија, низ сличен мост, направен од мечеви и ножеви, мора да помине јунакот Вејнаминен, но и шаманите кои во транс патуваат кон оној свет наречен „Тоунела”. Аналогни елементи (мост од седум стрели и седум даски, мост од сабји или скали од ножеви) се јавуваат во текот на одредени иницијациски искушенија во Јапонија, како и во кругот на таоистичките магиско-религиски ритуали (саи-конг $)^{20}$.

Во рамките на петтиот исламски шарт и случувањата на Судниот Ден, се вели дека по наредба на Алах, преку Џехнемот па се до Џеннетот ќе се создаде мост наречен Сират, кој ќе биде потенок од влакно и поостар од сабја. На секој човек ќе му биде наредено да помине преку него. Некои ќе го поминуваат со брзина на молња, некои како ветар, некои со брзина на галопирачки коњ, а други пак пеш. Оние кои го заслужиле Џеннетот, ќе го поминат мостот, а пак оние кои го заслужиле Џехнемот ќе се лизнат и ќе паднат од Сиратот во него ${ }^{21}$. Муслиманите од Куча (Србија) верувале дека душата патува до рајот по острицата на голема сабја. Ова патување трае 3000 години, а кој нема да го издржи, ќе падне во пеколот ${ }^{22}$. Во рамките на исламската култура, оваа митска претстава нашла и своја обредна манифестација. Тука мислиме на дервишките сеанси во кои, покрај другите обредни контакти со остри орудија и оружје, спаѓа и стоењето на острица на сабја (T. IV: 1$)^{23}$. Претстави за душата која ползи по сечило (острица на коса или срп) се забележени и во фолклорните традиции на Полесјето ${ }^{24}$. Во оваа категорија може да се стави

\footnotetext{
${ }^{20}$ M. Elijade, op. cit., стр. 331, 351, 352.

${ }^{21}$ Основни податоци: А. Али-Заде, Исламский энциклопедический словарь, Ансар 2007 (сират); називот на овој мост има персиско потекло (M. Elijade, op. cit., стр. 351).

${ }^{22}$ С. Зечевић, ор. сіt., стр. 28.

${ }^{23}$ M. Pero, The fakir dervishes of Prizren во: Photojournalism, <http://www.michelepero.it/english/fotografia_reportage.php?tipo=dervisci> [превземено: 10.01.2011].

${ }^{24}$ Л.Н. Виноградова, ор. сін., стр. 306.
} 
и мостот Чинват кој во древноиранските традиции е претставен како „потенок од влакно и поостар од брич” (види натаму).

Митската парадигма на „мостот - сечило” нашла своја манифестација во средновековните (T. IV: 3-5) и подоцнежни ликовни дела (T. IV: 2), но и во разни циркуски точки кои се состојат во одење по скали или друг вид реквизити сочинети од остри сечила ${ }^{25}$.

\section{д) Мост од влакно т.е. конец}

Во Србија се забележени верувања дека патот до рајот води преку пропаст (некаде како еквивалент на пеколот), над која е префрлен мост. Доколку душата којашто стои пред него е праведна, мостот е широк и таа лесно го поминува, но ако е грешна, тој се стеснува до дебелина на влакно и душата паѓа. Во Црна Гора е забележено слично предание според кое, меѓу рајот и пеколот стои мост тенок колку едно влакно, кој на душите им се чини дека е широк колку греда. Штом на него застане грешна душа, влакното се кине и таа паѓа во бездната, каде ја дочекуваат ѓволите и ја мачат. Во една песна запишана од Вук Караџиќ се вели како Св. Петар ја враќа назад од рајските порти сопствената мајка, советувајќи ја да оди по мостот: „,... те настављај све влаканце, / све влаканце по влаканце, / и по њему у рај пођи!”. Но, овој потег не успева (,...прекиде се то влаканце, / паде мајка усред пакла.”). Во некои случаи, како водител низ овој мост се појавува Св. Арханѓел ${ }^{26}$. Во некои подрачја на Србија, жените не се чешлале во периодот од 40 дена по смртта на умрениот, за да не го пореметат преминувањето на неговата душа по мостот влакно (се верувало дека тој премин трае точно толку денови) ${ }^{27}$. Верувања мошне слични на наведените се забележени и во Бугарија.

${ }^{25}$ М. Макаров, ор. cit., стр. 102, 226.

${ }^{26}$ С. Зечевић, ор. cit., стр. 28, 29; M. Mencej, Simbolika niti in predenja v evropski folklori, „Studia Mythologica Slavica” 13, 2010, стр. 156, 157; В.С. Караџић, Српске народне пјесме, т. I, Нолит, Београд 1969, стр. 100, 101 (бр. 208); N. Nodilo, Stara vjera Srba $i$ Hrvata, Split 1981, стр. 523. Мошне е индикативно што според верувањата, пијаниците и жените со послободно однесување го преминуваат овој мост без особени тешкотии, додека невините девојки - многу потешко (С. Зечевић, op. cit., стр. 28, 29).

${ }^{27}$ С. Зечевић, op. cit., стр. 29. 
Аналогни претстави постоеле и во рамките на староиранските традиции, според кои царството на врховниот бог Ахурамазда е лоцирано зад врвот Елбрус, одделено од овој свет со бездна. Преку неа поминува мостот Чинват под кој се наоѓа царството на Ахриман богот на темнината и злото. Всушност, тој е лоциран во „Центарот на светот” т.е. „средиштето на Земјата”, ги поврзува Земјата и Небото, додека под него се наоѓа и отворот кон Долниот свет. За праведниците тој е широк и тие можат слободно да минат низ него кон рајот, а за грешните се стеснува колку влакно или сечило од брич. Овој мост го чуваат две кучиња, додека душите ги придружува божествена дева која праведните ги преведува кон рајот, а грешните ги турка во темнината. Според одредени текстови, при преминот на човековата душа низ овој мост всушност се случува борба меѓу демоните кои неа сакаат да ја турнат во Пеколот и духовите - заштитници кои се стремат да им се спротивстават ${ }^{28}$. Мостот со истите обележја мораат да го поминат и алтајските шамани, на патот до престојувалиштето на Ерлик-Кан т.е. светот на мртвите. Тој е тенок колку влакно и распнат над морето, на чие дно се гледаат коските на безбројните шамани кои не успеале да го преминат поради своите гревови ${ }^{29}$.

Мост „тесен колку влакно” кој го спојува „овој свет” со рајот, е наведен во „Визијата на Св. Павле”, а идентичен мост меѓу земјата и „,вездените предели” се споменува и кај арапските писатели и мистици. Како што веќе напомнавме, во рамките на исламската догматика тоа е мостот Сират, претставен како сечило или како тенко влакно $^{30}$. Ваквиот мост - влакно се јавува и во народните приказни, повторно како симбол на преминот меѓу овој и „оној свет”

Во некои случаи, мостот тенок колку влакно се алтернира со мостот во вид на тенок конец или јаже. Во една стара англиска песна,

${ }^{28}$ M. Elijade, op. cit., стр. 292-294; Авеста в русских переводах (1861-1996), ред. И.В. Рака, Санкт-Петербург 1998, стр. 469, 470 (Видевдат, 13. 3, 9; 19. 29-30; Ясна, 46.10; 51, 12-13); Мифы народов мира, II, стр. 629; С. Зечевић, ор. сіt., стр. 30.

${ }^{29}$ M. Elijade, op. cit., стр. 162-164.

${ }^{30}$ Ibidem, стр. 351.

31 V.J. Prop, Historijski korijeni bajke, Sarajevo 1990, стр. 513, 514; Бототина и иесть его братьев во: Грузинские народнье скаски, <http://www.georgianweb.com/ language/rus/skaski/skazka14.html> [превземено: 04.01.2011]. 
која се пеела во текот на бдеењето над покојникот, се спомнува „грозен мост, не поширок од конец"32. Во тајните кинески здруженија, иницијациските патувања се одвивале низ „златен мост” претставен преку јаже од бело сукно ${ }^{33}$.

Веруваме дека горе прикажаните митски парадигми на преминот преку тесниот мост, барем делумно ја открија семиотичката димензија на современата циркуска точка „одење по јаже”. Може да се претпостави дека во одредени древни и архаични култури, таа се изведувала како обредна инсценација и тоа во во разни случаи и поради различни причини. Во одредени календарски или други преодни моменти, нејзина цел можело да биде повторувањето на чинот на создавањето на вселената т.е. евоцирање на нејзините идеални почетни состојби, кога космичките зони не биле одделени, поради што постоела непосредна комуникација меѓу земјата и небото, луѓето и боговите. Како што покажуваат наведените примери, втор повод можеле да бидат погребните традиции, кога обредното одење по јаже (или греда) се изведувало поради есхатолошки цели - за да му се помогне на покојникот т.е. неговата душа, во успешното преминување на тесниот мост кој води кон „оној свет”. Ова дејствие можеле да го изведуваат и шаманите, како приказ на нивното духовно патување на „оној свет”.

Денес, во современите циркуски точки од жанрот „одење по јаже" останало само визуелното, додека сите тука прикажани значенски т.е. симболички содржини се јавуваат исклучиво како ментална слика, формирана во свеста и подсвеста на публиката. Таа се индуцира врз база на согледувањето (читање или визуелна перцепција) на тука прикажаните митско-религиски дејствија, или пак како продукт на интеракцијата со архетипските претстви од потсвеста т.е. колективното несвесно.

${ }^{32}$ Saxo 1.8 .14 p. 30, според: M.L. West, Indo-European Poetry and Myth, Oxford 2007, стр. 390, 391; во приказните: V.J. Prop, op. cit., стр. 513, 514.

${ }^{33}$ M. Mencej, op. cit., стр. 155, 156; J. Chevalier, A. Gheerbrant, op. cit., стр. 416. 


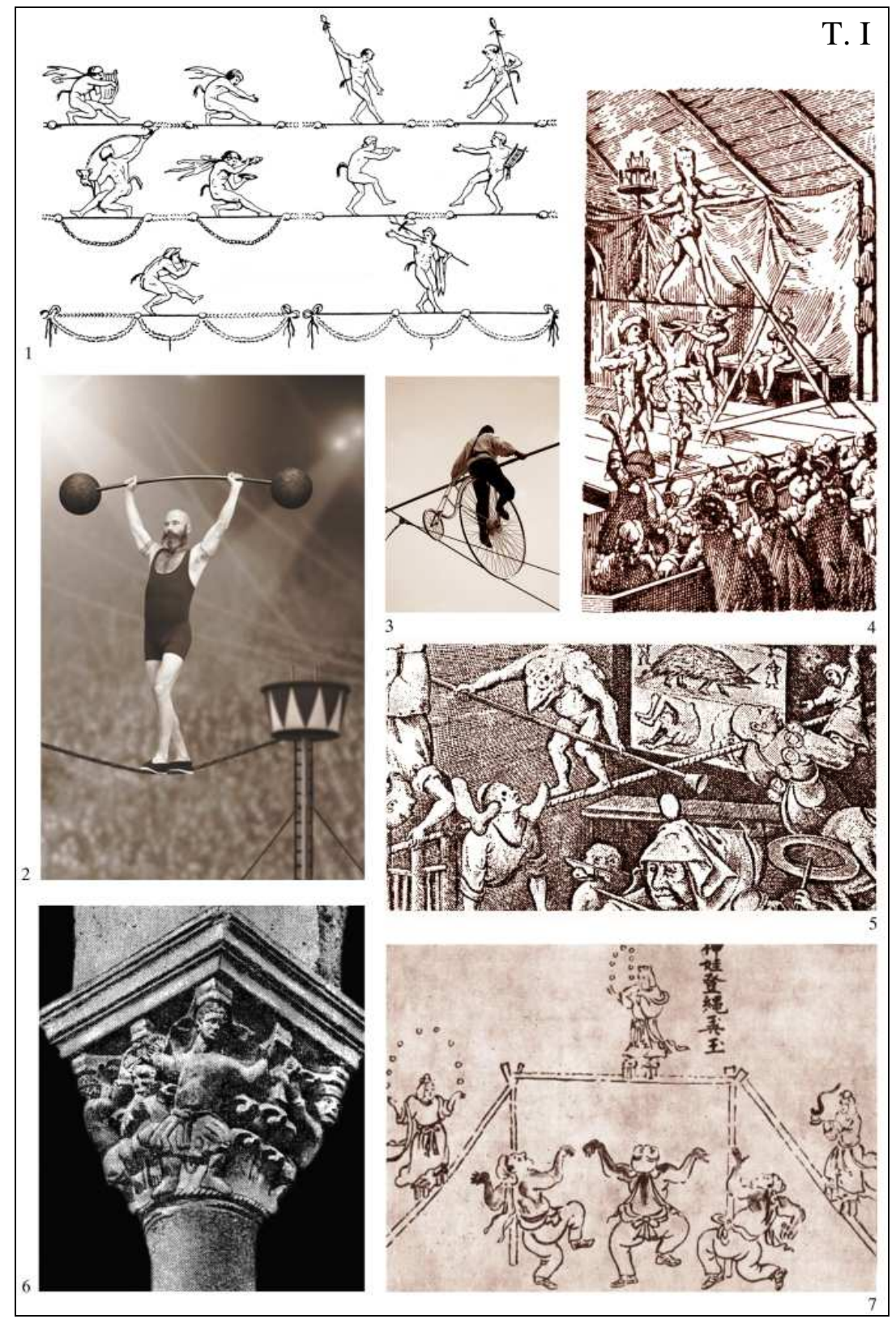




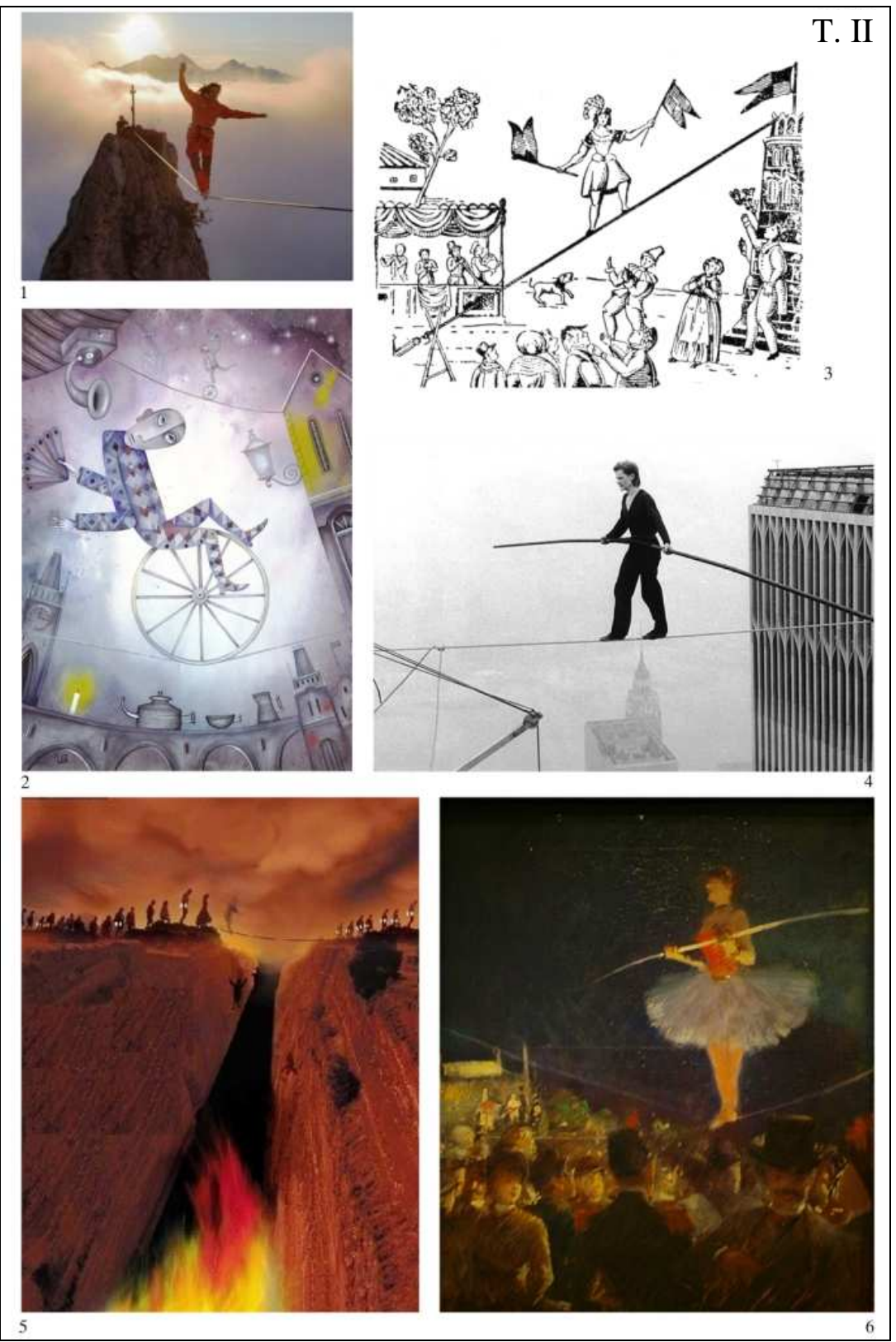




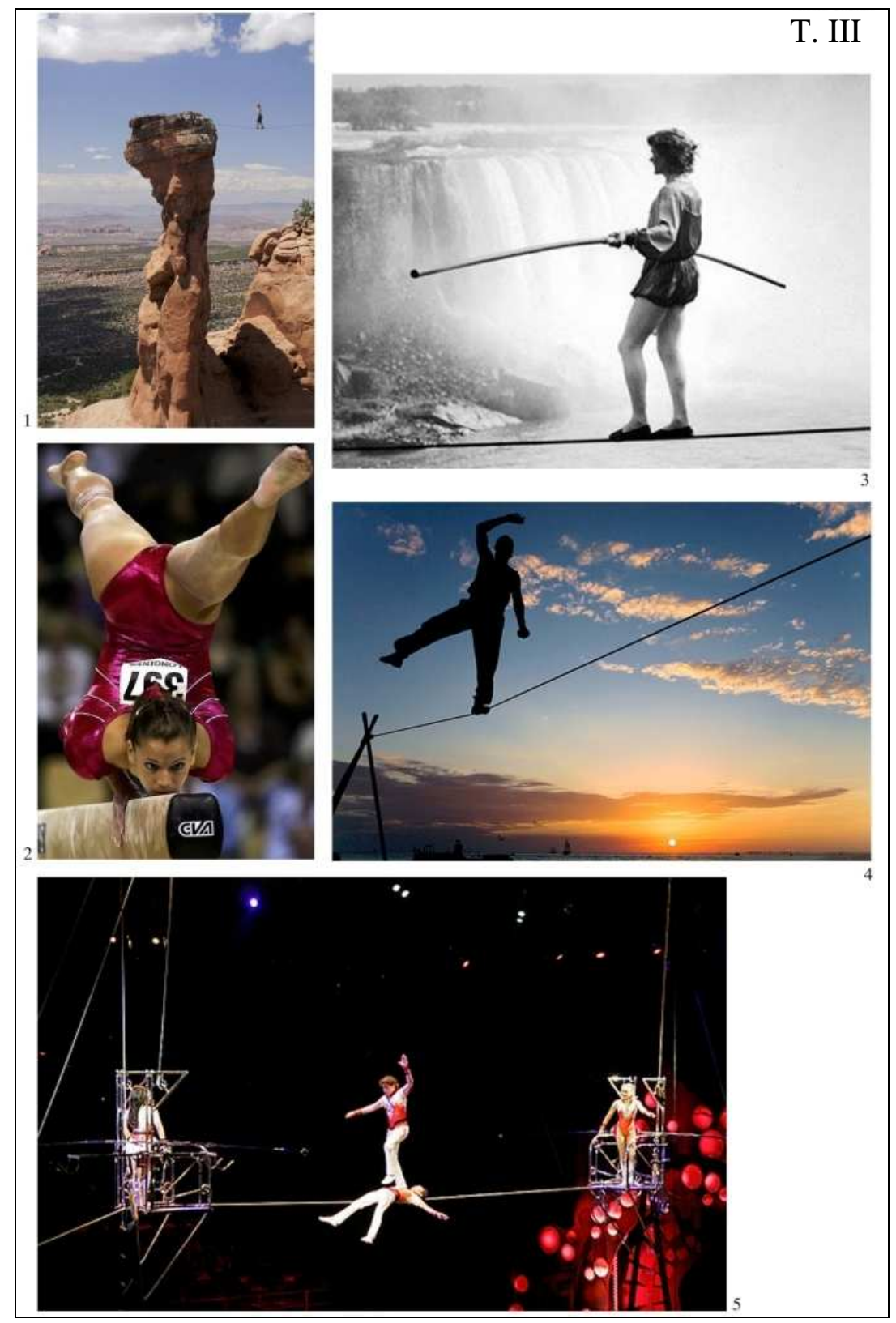




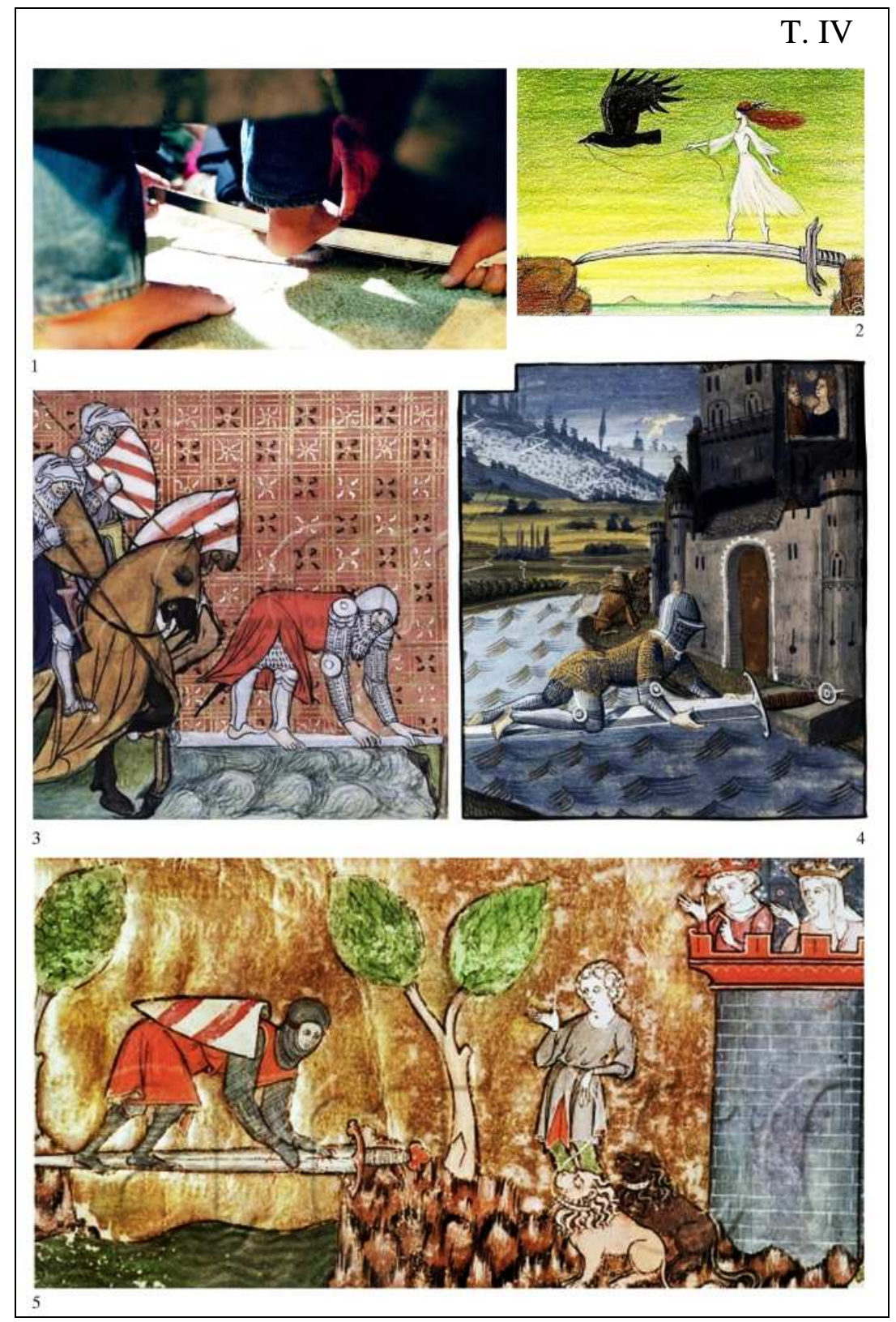




\section{Илустрации}

T. I. 1. Одачи по јаже, римски период (А.Я. Шнеер, Р.Е. Славский, Цирк, стр. 142); 4. Танц на јаже, гравура, 18. век (А.Я. Шнеер, Р.Е. Славский, Цирк, стр. 143); 5. Демон - одач по јаже, гравура од 1565 г., според сликата на Питер Бројгел „Падот на магот Хермоген”, „Реиксмузеум”, Амстердам (В.П. Даркевич, Народная, Т. 1: 4); 6. Танцувачи на јаже, капител, 12. век, катедрала во Отранто, Апулија, Италија (В.П. Даркевич, Народная, Т. 1: 3); 7. Девојки жонглираат стоејќи на јаже, цртеж, 8. век, Јапонија (В.П. Даркевич, Народная, Т. 1: 1).

T. II. 3. Одење по косо оптегнато јаже, гравура, 18. век (А.Я. Шнеер, Р.Е. Славский, Цирк, стр. 143); 4. Филип Пети, оди по јаже распнато меѓу двата облакодери-близнаци на светскиот трговски центар во Њујорк (Philippe Petit // Wikipedia, The Free Encyclopedia.); 5. Мостот Сират <http://open.az/islam/print: page, 1,100585-predstav....html> [превземено: 02.04.2012]; 6. Jean Louis Forain, „Одач по јаже”, втора половина на 19. век, Art Institute of Chicago.

T. III. 3. Charles Blondin, оди по јаже распнато над Нијагарините водопади, 1859 г. (Charles Blondin, Wikipedia, The Free Encyclopedia).

T. IV. 1. Стој со голи нозе на сабја, дервишка сеанса, Призрен, Косово (M. Pero, The fakir dervishes); 2. „Сабjа мост”, Rytarey <http://cgi.ebay.com/ACEO-ATC-RAVEN-CROW-RYTA-SWORD-BRIDGE-BIRD-FOLK-ART-/390281739014> [превземено: 02.04.2012]. „Ланцелот ползи по мост во облик на меч” - илуминации од средновековни ракописи: 3. „Livre de Messire Lancelot du Lac”, Bibliotheque de L'Arsenal, Paris, France. 4. „Lancelot du Lac”, 1470 г. (автор на илуминацијата Evrard d'Espinques); 5. манускрипт „The Vulgate Cycle”.

Останатите приложени ликовни прилози се современи (неавторизирани) илустрации и фотографии, објавени на интернет - мрежата.

\section{Литература}

Авеста в русских переводах (1861-1996), ред. И.В. Рака, Санкт-Петербург 1998.

Али-Заде А., Исламский энииклопедический словарь, Ансар 2007. <http://slovarislam.ru/books/s.html\#Sirat42> [превземено: 25.12.2011].

Balance beam, Wikipedia, The Free Encyclopedia, <http://en.wikipedia.org/wiki/Balance_beam> [превземено: 29.12.2011].

Березкин Ю.Е., Тематическая классификация и распределение фольклорно-мифологических мотивов по ареалам, <http://www.ruthenia.ru/folklore/berezkin/index_left.htm> [превземено: 27.12.2011]. 
Бототина и шесть его братьев, во: Грузинские народные скаски, <http://www. georgianweb.com/language/rus/skaski/skazka14.html> [превземено: 04.01.2011].

Charles Blondin, Wikipedia, The Free Encyclopedia, <http://en.wikipedia.org/wiki/ Charles_Blondin> [превземено: 08.01.2011].

Чаусидис Н., Хиерогамија и юене ликовне претставе у древним и архаичним културама. Традииионална естетска култура, во: Ерос, ур. Д. Жунић, Ниш 2012 (во печат).

Chausidis N., Juggling and its Mythical Paradigms in the Pictorial Medium, во: Jubilee Collection, dedicated to the $70^{\text {th }}$ anniversary of Prof. DSc Ivan Marazov, Sofia 2012.

Чаусидис Н., Љуљашка и љуљање између обреда, игре и уметности, во: Традииионална естетска култура: Игра, ур. Д. Жунић, Ниш 2011, стр. 35-63.

Чаусидис Н., Космолошки слики (симболизачија и митологизација на космосот во ликовниот медиум), t. I-II, Скопје 2005.

Čausidis N., The Black Man in the Mythical Tradition of Macedonia, во: Interpretations, vol. 3, Figures of Memory: Black Arab, yp. K. Kulavkova, Skopje 2009, стр. 73-104.

Chevalier J., Gheerbrant A., Rječnik simbola, Zagreb 1987.

Даркевич В.П., Народная культура средневековья. Светская праздничная жизнь в искусстве IX-XVI вв., Москва 1988.

Elijade M., Šamanizam i arhajske tehnike ekstaze, prev. Z. Stojanović, Novi Sad 1985.

A history of circus, во: Victory and Albert Muzeums / Collections / Theatre \& Performance / Theatre and Performance Features/, <http://www.vam.ac.uk/collections/theatre_performance/features/history_of_circus/circus_acts/index.html > [превземено: 06.01.2011].

Караџић В.С., Српске народне пјесме, т. І, Београд 1969.

Макаров С.М., Шаманы, масоны, иирк. Сакральные истоки цииркового искусства, Москва 2009.

Matić V., Psihoanaliza mitske prošlosti, Beograd 1976.

Mencej M., Simbolika niti in predenja v evropski folklori, „Studia Mythologica Slavica" 13, 2010, стр. 151-170.

Nodilo N., Stara vjera Srba i Hrvata, Split 1981.

Pero M., The fakir dervishes of Prizren, во: Photojournalism, <http://www.michelepero.it/english/fotografia_reportage.php?tipo=dervisci> [превземено: 10.01.2011].

Philippe Petit, Wikipedia, The Free Encyclopedia, <http://en.wikipedia.org/wiki/ Philippe_Petit> [превземено: 29.12.2011].

Prop V. J., Historijski korijeni bajke, Sarajevo 1990. 
Софрониевски В., По трагите на божилакот, „Годишен зборник на филозофскиот факултет" 62, 2009, стр. 365-384.

Срејовић Д., Цермановић А., Речник грчке и римске митологије, Београд 1987.

Stone A., The Perilous Bridge, „At the Edge” no. 1, 1996, <http://www.indigogroup. co.uk/edge/pbridge.htm> [превземено: 25.12.2011].

Шнеер А.Я., Славский Р.Е., Цирк: маленькая энциклопедия, Советская энциклопедия, Москва 1973.

Топоров В.Н., Мост, во: Мифы народов мира, II, Советская энщиклопедия, Москва 1982, стр. 176-177.

Валенцова М.М., Прялка, во: Славянские древности (Этнолонгвистический словарь), т. 4: Международные отношения, Москва 2009, стр. 331-334.

Виноградова Л.Н., Мост, во: Славянские древности (Этнолонгвистический словарь), т. 3: Международные отношения, Москва 2004, стр. 303-307.

Водинчар Е., Митологично-езическите централии в „историческата” песен за Тодорка Робинка, Електронно списание LiterNet, 08.01.2001, no. 1 (14), <http://liternet.bg/publish2/evodinchar/todorka.htm> [превземено: 06.01.2011].

West M.L., Indo-European Poetry and Myth, Oxford 2007.

Зечевић С., Култ мртвих код Срба, Београд 1982.

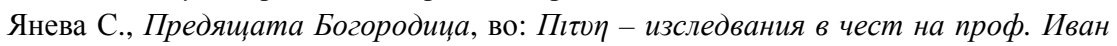
Маразов Маразов, ред. Р. Гичева, К. Рабаджиев, София 2002. 
